\title{
8. REFERENCES
}

1. Moon L, Rahman N and Bhatia K. Australia's children: Their health and wellbeing 1998. Canberra: Australian Institute of Health and Welfare, 1998.

2. Commonwealth Department of Human Services and Health. The health of young Australians: A national health policy for children and young people. Canberra: AGPS, 1995.

3. Nossar V and Alperstein G. Monitoring child health (guest editorial). N S W Public Health Bull 1998; 9: 71-72.

4. Jorm L. Surveillance of child health in NSW: Status, gaps, and developments. NS W Public Health Bull 1998; 9: 73-75.

5. Williamson M, Baker D and Jorm L. The NSW Health Survey Program: Overview and methods, 1996-2000. N S W Public Health Bull 2001; 12(S-2).

6. Child, Adolescent and Family Health Service. Health Goals and Targets for Australian Children and Youth. Canberra: Child, Adolescent and Family Health Service and Department of Human Services and Health, 1992.

7. Commonwealth Department of Health and Family Services. The National Health Plan for Young Australians. Canberra: DHFS, 1996.

8. NSW Department of Health. Caring for health: Caring for children. A discussion paper towards the development of a child health policy for NSW. Sydney: NSW Department of Health, 1996.

9. NSW Department of Health. The start of good health: Improving the health of children in NSW. Sydney: NSW Department of Health 1999.

10. O'Sullivan B, Alperstein G, and Mahmic A. Development of a child and youth health report card for Central Sydney. N S W Public Health Bull. 2000; 12(11): 302-307.

11. Public Health Division, The health of the people of New South Wales-Report of the Chief Health Officer 1997. Sydney: NSW Department of Health, 1997.

12. Australian Bureau of Statistics. Children, Australia: A social report. Canberra: Australian Bureau of Statistics, 1999.

13. Al-Yaman F, Bryant M, Sargeant H. Australia's children: their health and wellbeing 2002. Canberra: AIHW, 2002.

14. NSW Inpatients Statistics Collection (HOIST). Sydney: Centre for Epidemiology and Research, NSW Department of Health, 1999-2000.

15. Australian Bureau of Statistics. National Health Survey 1995. Canberra: Commonwealth of Australia, 1995.

16. Australian Institute of Health and Wellbeing. National Survey of Lead in Children 1995. Canberra: AIHW, 1995.

17. Notifiable Diseases Database (HOIST). Sydney: NSW Department of Health, 1999-2000.

18. Australian Bureau of Statistics. Children's Immunisation and Health Screening Survey 1995. Canberra: ABS, 1995.

19. Australian Bureau of Statistics. Child Immunisation Questionnaire 1995, Canberra: ABS, 1995.

20. NSW Department of Health. NSW Health Promotion Survey, May 1994. Sydney: NSW Department of Health, 1994.

21. Australian Bureau of Statistics and Commonwealth Department of Health and Family Services. National Nutrition Survey: Foods eaten, Australia 1995. Canberra: ABS, 1999.

22. Public Health Division. Electronic Report of the 1997 and 1998 NSW Health Surveys. Available online at www.health.nsw.gov.au/ public-health/nswhs, accessed 23 August 2002.
23. Booth ML, Okley AD, Chey T, Bauman AE and Macaskill P. Epidemiology of physical activity participation among NSW school students. Aust N Z J Public Health 2002; 26: 371-371.

24. Midwives Data Collection (HOIST). Sydney: Centre for Epidemiology and Research, NSW Department of Health, 1999-2000.

25. ABS Mortality Data (HOIST). Sydney: Centre for Epidemiology and Research, NSW Department of Health, 1999-2000.

26. Centre for Behavioural Research in Cancer. Australian secondary students over-the-counter and illicit substances use in 1996, Melbourne: Anti-Cancer Council of Victoria, 1998.

27. Zubrick SR, Silburn SR, Garton A, Burton P, Dalby R, Carlton J, Shepherd C and Lawrence D. Western Australia Child Health Survey Developing health and wellbeing into the nineties. Perth: Western Australia: Australian Bureau of Statistics and the Institute for Child Health Research, 1995.

28. Williamson M, Jorm L, Cardona M, Chey T. Blacktown Health Survey 1993. Sydney: Western Sydney Area Health Service, 1994.

29. Australian Bureau of Statistics. Survey of Disability, Ageing and Handicap 1993. Canberra: ABS, 1993.

30. Sawyer MG, Arney FM, Baghurst PA, Clark JJ, Graetz BW, Kosky RJ, Nurcombe B, Patton GC, Prior MR, Raphael B, Rey J, Whaites LC and Zubrick SR. Child and Adolescent Component of the National Survey of Mental Health and Wellbeing. The mental health of young people in Australia. Canberra: Mental Health and Special Programs Branch, Commonwealth Department of Health and Aged Care, 2000.

31. Prior M, Sanson A, Smart D and Oberklaid F. Pathways from Infancy to Adolescence: Australian Temperament Project 19832000. Canberra: Australian Institute of Family Studies, 2000.

32. Cater K, Stewart J, Davies M, Szuster F, Allister J, Slade G and Spencer J. National Dental Telephone Interview Survey 1994. Adelaide: Australian Institute of Health and Welfare, Dental Research and Statistics Unit. Adelaide: University of Adelaide, 1994.

33. Emergency Department Information System (HOIST). Sydney: Centre for Epidemiology and Research, NSW Department of Health, 1999-2000.

34. Epstein N B, Baldwin LM and Bishop DS. The McMaster Family Assessment Device. Journal of Marital and Family Therapy.1983; 9: 171-180.

35. Landgraf JM, Abetz L and Ware JE. The Child Health Questionnaire User's Manual. First Edition. Boston, MA: The Health Institute, New England Medical Centre, 1996.

36 Division of Human Nutrition. CSIRO National Nutrition Survey 1993. Adelaide: DNN, 1993. Available online at www.csiro.au/csiro/achievem/healt12.htm, accessed 19 September 2002.

37. Australian and New Zealand Food Authority. Eat Well Tasmania Surveys 1995-1999. Hobart: Menzies Centre for Population Research, University of Tasmania, 2000.

38. Trotter L and Mullins R. Environmental tobacco smoke: public opinions and behaviour. Trotter L and Mullins R (editors). Quit Evaluation Studies 9. Melbourne: Quit Victoria, 1998; 27-42.

39. TVW Telethon Institute for Child Health Research. The Western Australian Pregnancy and Infancy Survey 1995. Perth: University of Western Australia, 1995. 
40. TVW Telethon Institute for Child Health Research. The Research Study of Birth Defects Part 1 Pregnancy Questionnaire 1997-2000. Perth: University of Western Australia, 2001.

41. Scott JA. Factors associated with the duration of breastfeeding amongst women in Perth, Australia. Acta Paediatrica 1999 88 (4): 416-21.

42. Smith BJ, Ferguson C, McKenzie J, Bauman A and Vita P. Impacts from repeated mass media campaigns to promote sun protection in Australia. Health Promotion International 2002; 17(1): 51-60.

43. Northern Sydney Area Health Service. The NSW Youth Sports Injury Report, 1997. Sydney: NSAHS, 1997.

44. Western Sydney Area Health Service. Holroyd Health Survey 1995, Sydney: WSAHS, 1995.

45. Hort KP. Health problems and service use by parents of normal infants in the first 6 months of life. J Paedatr Child Health 1992; 28: 286-290.

46. Onyx $\mathrm{J}$ and Bullen P. Measuring social capital in five communities in NSW: An analysis. Sydney: Centre for Australian Community Organisations and Management, University of Technology, 1997.

47. Bailey FK, Nossar V, Jeffs DA, Smith W and Chey T. An Evaluation of the NSW Personal Health Record, 1992. Sydney: NSW Department of Health, 1992.

48. Rissel C, McLellan L and Bauman A. Factors associated with delayed tobacco uptake among Vietnamese and Arabic youth in Sydney, NSW. Aust N Z J Public Health 2000; 24(1): 22-28.

49. McIntyre P, Wang H, Gilmour R, Heath T, Jorm L. Williamson M, Kakakios A, Gilbert GL and Mellis C. Risk factors for invasive pneumococcal disease. Paper given at the International Symposium on Pneumococci and Pneumococcal Diseases, Sun City, South Africa, 2000.

50. Taylor, A. Health Goals and Targets Health Priority Areas Survey, 1998. Adelaide: SERCIS, Centre for Population Studies in Epidemiology, Epidemiology Branch, South Australian Health Commission, Department of Human Services, South Australia, 1998.

51. Taylor, A, Grande ED and Wilson D. Health Survey of Adelaide's Northern Health Planning Area February 1996. Adelaide: SERCIS, South Australian Health Commission, 1996.
52. Taylor A. The South Australian Survey on disability prevalence, November 1996-February 1997. Adelaide: South Australian Health Commission, 1997.

53. Centre for Population Studies in Epidemiology. South Australian Health Omnibus Survey Autumn 1995. Adelaide: South Australian Department of Human Services, 1995.

54. Centre for Population Studies in Epidemiology. South Australian Health Omnibus Survey Spring 1995. Adelaide: South Australian Department of Human Services, 1995.

55. Epidemiology Services Unit. Queensland Public Health and Media Reach Survey 1997. Brisbane: Queensland Department of Health, 1997.

56. Epidemiology Services Unit. Queensland Public Health and Media Reach Survey 1996. Brisbane: Queensland Department of Health, 1996.

57. Child Support Team. National Longitudinal Survey of Children. Ottawa: Canadian Department of Justice, 1993.

58. United States Department of Agriculture. Measuring Children's Food Security in US Households, 1995-1999. Available online at www.ers.usda.gov/publications/Fanrr25, accessed 23 October 2002.

59. Ware JE, SnowKK, Kosinski M and Gandek B. SF-36 Health Survey Manual and Interpretation Guide. Boston, Mass: The Health Institute, New England Medical Centre, 1993.

60. Public Health Division. New South Wales Older People's Health Survey 1999. Sydney: NSW Department of Health, 2000.

61. Australian Bureau of Statistics, 1996 NSW Census Data (HOIST). Sydney: Centre for Epidemiology and Research, NSW Department of Health, 1999.

62. Astbury L and Jorm L. The Auburn and Holroyd Health Survey 1995. Sydney: Western Sydney Area Health Service, 1997.

63. Alreck PL and Settle RB. The Survey Research Handbook. Second edition. Chicago: Irwin, 1995.

64. Groves RM and Lyberg LE. An Overview of Non Response Issues in Telephone Surveys. Groves RM, Biemer PP, Lyberg LE, Massey JT, Nicholls WL, Waksberg J (editors). Telephone Survey Methodology. New York: John Wiley and Sons, 1988.

65. Centre for Epidemiology and Research, NSW Department of Health. New South Wales Child Health Survey 2001. N S W Public Health Bull 2002; 13(S-4). 